CARADDE: Jurnal Pengabdian Kepada Masyarakat
$\begin{gathered}\text { https://journal.ilininstitute.com/index.php/caradde } \\ \text { Volume 2 | Nomor 2 | Februari | 2020 } \\ \text { e-ISSN: 2621-7910 dan p-ISSN: 2621-7961 }\end{gathered}$
DOI: https://doi.org/10.31960/caradde.v2i2.291

\title{
Perencanaan Peningkatan Kapasitas Produksi Tepung Mendoan Instan
}

\author{
Undri Rastuti ${ }^{1}$, Hartiwi Diastuti ${ }^{1}$, Wihiatmoko Herry Purnomo ${ }^{1}$, Sutarmin ${ }^{2}$
}

\section{Keywords :}

Tempe;

Mendoan;

Tepung instan;

Kapasitas produksi,

Pengemasan

\section{Corespondensi Author}

Kimia FMIPA, Universitas Jenderal

Soedirman

Jln Arsantaka no 2A RT 5 RW 4

Arcawinangun, Purwokerto

Email: undrirastuti@yahoo.co.id

\section{History Artikel}

Received: 07-September-2019;

Reviewed: 17-Oktober-2019;

Accepted: 29-Oktober-2019;

Avalaible Online: 16-Desember-2019;

Published: 04-Februari-2020;
Abstrak. Mendoan adalah makanan khas masyarakat Banyumas yang berbahan dasar tempe. Bagi masyarakat Banyumas makan mendoan itu sudah merupakan budaya setiap hari. Tiada hari tanpa makan mendoan. Untuk membuat mendoan yang mudah dan cepat diperlukan tepung yang praktis/instan/siap pakai. Produksi tepung mendoan instan dalam skala rumah tangga sangat terbatas dan selalu kewalahan melayani permintaan konsumen. Setiap hari hasil produksinya habis terjual, bahkan sampai menolak pesanan.. Untuk mengatasi permasalahanpermasalah tersebut tim pengabdian masyarakat Universitas Jenderal Soedirman dan Universitas Peradaban berusaha untuk membantu meningkatkan kapasitas produksi dengan cara memberikan bantuan alat-alat produksi. Selain itu juga akan dilakukan pendampingan, penyuluhan dan pelatihan meliputi: penggunaan dan perawatan alat-alat modern.

\section{PENDAHULUAN}

Mendoan adalah salah satu makanan khas Banyumas yang berbahan dasar tempe. Mendoan berasal dari bahasa Banyumasan yaitu mendo yang berarti setengah matang. Makanan ini sangat populer di Kabupaten Banyumas, bahkan sudah banyak di kenal di beberapa kota di Indonesia. Mendoan hingga saat ini sudah sangat banyak penikmatnya karena rasanya yang enak dan tentunya harganya pas untuk kalangan menengah ke bawah. Biasanya makanan ini di sajikan saat kumpul-kumpul dengan keluarga maupun orang lain. Aktifitas ini dikenal dengan sebutan "Medang". Medang biasanya menghidangkan makanan-makanan khas Banyumas, yang salah satunya adalah mendoan ini, untuk minumnya biasanya adalah teh hangat dan kopi hangat.
Di Kabupaten Banyumas banyak sekali penjual gorengan yang satu ini dan umumnya mulai ditemui sore hingga malam hari. Harga yang ditawarkan beragam mengingat perbedaan ukurannya, biasanya berkisar antara 1000 dapat 1 mendoan sampai 2000 dapat 3 mendoan.

Mendoan sekarang tidak hanya dinikmati kelas menengah ke bawah, tetapi juga sudah menjadi makanan berbagai kalangan, baik kalangan bawah, menengah maupun kalangan atas. Mendoan tidak hanya dijual di warung makan, tetapi juga tersedia di rumah makan, restoran dan hotel di Banyumas. Setiap rumah makan, restoran dan hotel di Banyumas hampir bisa pasti menyediakan menu mendoan. Berasa belum ke Banyumas jika belum makan mendoan. Mendoan juga sudah menjadi oleh-oleh yang bisa dibawa keluar kota dalam bentuk tempe 
tipis yang belum jadi dan tepung yang sudah diberi bumbu secara terpisah.

Pada prinsipnya mendoan terdiri dari bahan baku: tempe tipis, macam-macam tepung seperti tepung terigu, tepung beras, tepung maizena dan tepung aci (topioka), macam-macam bumbu yang dihaluskan seperti bawang putih, ketumbar, garam dan penyedap rasa. Para pecinta dan penyedia mendoan akan repot jika harus selalu menggerus bumbu dan membuat adonan setiap ingin menyajikan ke pelanggan ataupun disantap sendiri, padahal mendoan akan lebih nikmat jika disajikan ketiga masih hangat. Oleh karena itu mulai dikembangkan tepung mendoan instan.

Tepung mendoan instan adalah tepung yang sudah dikemas dan berisi campuran tepung dan bumbu sehingga pengguna tinggal menambahkan air dan irisan daun bawang saja sebelum digunakan untuk membaluri tempe yang kemudian digoreng. Keunggulan lain tepung mendoan instan adalah lebih hemat. Dengan menggunakan tepung mendoan instan, untuk membuat mendoan tidak lagi perlu membeli aneka bumbu lainnya yang mengeluarkan uang banyak, padahal hanya untuk menggoreng mendoan beberapa potong saja. Sementara dari sisi waktu, dengan tepung mendoan instan, lebih pendek waktu yang diperlukan untuk persiapan.

Melihat peluang yang sangat besar ini Bapak Heri Purwanto mulai tahun 2015 mendirikan usaha "Bramas Jaya" yang bergerak dalam pembuatan tepung mendoan instan di desa Bojongsari dengan kapasitas produk 600 bungkus perhari@150 gram. Tepung mendoan buatan "Bramas Jaya" ini laku keras dan tidak pernah bersisa tiap harinya. Berapapun hasilnya akan terjual habis pada hari itu. Karena permintaan yang selalu besar, maka pada tahun 2016, Bramas Jaya membuka pabrik kedua di Jl. Tri Murti No 10 Sokanegara, Purwokerto TimurBanyumas, dengan kapasitas yang sama.

Setiap hari UKM ini memproduksi tepung mendoan instan sebanyak 6 bal, setiap bal berisi 100 bungkus, masing-masing bungkus berisi 150 gram. Jumlah produksi tersebut dibuat dari bahan baku 3 sak (1 sak = $25 \mathrm{~kg}$ ) tepung terigu dan ditambah bahan lain seperti tepung maizena dan tepung aci (tapioca). Bahan baku ini dibeli setiap hari (sekali habis). Selain bahan baku tepung juga dibutuhkan bumbu-bumbu seperti bawang putih, ketumbar, garam dan bumbu masak. Kapasitas produksi yang dihasilkan masih sangat terbatas.

Proses produksi ini dilakukan dengan tahapan sebagai berikut: (1) Proses pencampuran tepung beras dengan bumbu (biang), (2) Pengayakan kasar, yaitu memisahkan bumbu (biang) yang kurang halus, (3) Pengeringan campuran, yaitu menghilangkan kandungan air dari biang, (4) Proses pencampuran tepung maizena dan aci, mencampur adonan tepung beras dan bumbu dengan tepung maizena dan aci, (5) Pencampuran dengan bumbu kering, (6) Pengayakan halus yaitu pengayakan dengan ayakan yang lebih halus, sehingga diperoleh campuran yang halus dan merata, (7) Proses pencampuran tepung terigu, yaitu mencampur semua campuran dengan tepung terigu, (8) Proses pengemasan (packaging), yaitu tepung mendoan instan ditimbang sesuai takaran dan dikemas dengan wadah plastik kemudian disealer.

Semua proses pembuatan tepung mendoan instan di atas dilakukan mulai dari jam $08.00 \mathrm{~s} / \mathrm{d} 17.00$, bahkan kadang harus lembur sampai malam jika ada pesananpesanan khusus.

Berdasarkan analisis situasi tersebut maka dilakukan upaya perencanaan peningkatan kapasitas produksi tepung mendoan instan "Barling Gold" hasil produksi skala rumah tangga (home industry) UKM Bramas Jaya.

\section{METODE}

Langkah-langkah pelaksananaan program pengembangan supaya tepung mendoan instan menjadi produk unggulan daerah.adalah (1) Focus Group Discussio (FGD) Tim PPPUD dengan Mitra: identifikasi dan analisis masalah yang dihadapi mitra "Bramas Jaya", penentuan permasalahan prioritas yang akan ditangani dalam kegiatan PPPUD, dan penentuan peserta kegiatan; (2) Persiapan dan perencanaan kegiatan: pemilihan dan penentuan pengadaan alat dan bahan yang diperlukan untuk pengabdian, pemilihan jenis pelatihan, yang disepakati untuk menangani permasalahan prioritas yang akan 
ditangani, penentuan ahli dan sumber daya yang diperlukan (narasumber) dalam kegiatan pelatihan/penyuluhan yang akan dilaksanakan, penentuan pengadaan alat dan bahan, penentuan jadual kegiatan.

Kegiatan-kegiatan yang dilaksanakan; Modernisasi alat produksi untuk peningkatan kapasitas dengan memberi bantuan mesin packaging otomatis dan pendampingan penggunaan dan perawatan alat packaging (pelatihan)

\section{HASIL DAN PEMBAHASAN}

Berdasarkan analisis situasi menunjukkan bahwa tepung mendoan instan "Barling Gold" merupakan salah satu hasil produksi skala rumah tangga (home industry) yaitu UKM Bramas Jaya. Saat ini setiap harinya dapat memproduksi 2 bal tepung ( 1 bal berisi 100 bungkus dengan berat @150 gram). Dalam sekali produksi selalu habis terjual dengan kontan (cash), yang dipasarkan oleh 1 orang marketing. Dalam 1 hari produksi dilakukan oleh 3 orang dengan bahan baku masih kurang dari 1 kwintal (sekitar $75 \mathrm{~kg} / 3$ sak tepung terigu). Saat ini hasil produksi tersebut tidak bisa maksimal memenuhi semua pesanan, terbukti bahwa dalam satu hari proses produksi selalu langsung habis terjual.

Perencanaan peningkatan produksi dilakukan dengan melakukan pengamatan terhadap semua permasalahan yang ada. Kapasitas produksi yang masih terbatas, sehingga belum bisa memenuhi kebutuhan pasar. Keterbatasan produksi ini disebabkan karena semua proses produksi yang masih serba manual yang membutuhkan waktu proses cukup lama. Permasalahan alat-alat produksi yang manual membutuhkan waktu lama

Saat membuat bumbu biang, yaitu alat yang digunakan mencampur masih memakai ember plastik. Akan lebih cepat jika menggunakan mixer roti yang besar

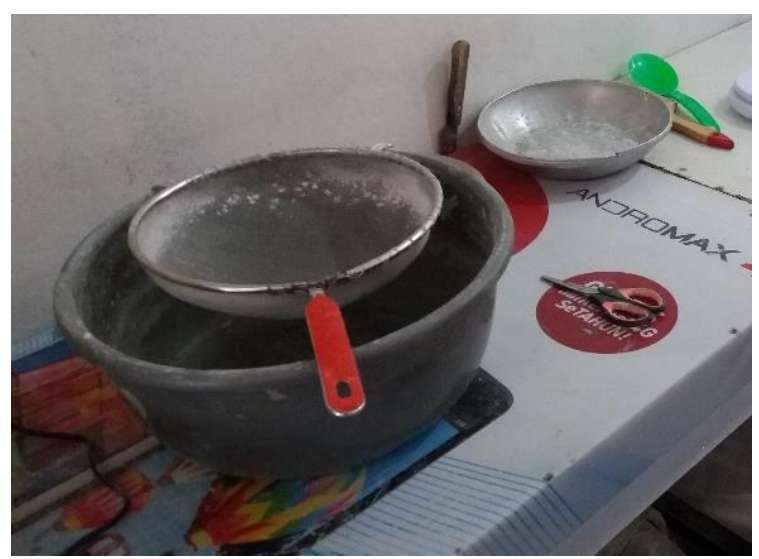

Gambar.1 Ayakan Pembuatan bahan

Ayakan yang digunakan masih manual. Akan lebih praktis jika alat ayakannya bermesin

Pengeringan campuran saat menghilangkan kandungan air dari biang dilakukan dengan open sederhana menggunakan kompor, akan lebih cepat jika digunakan open digital dengan listrik.

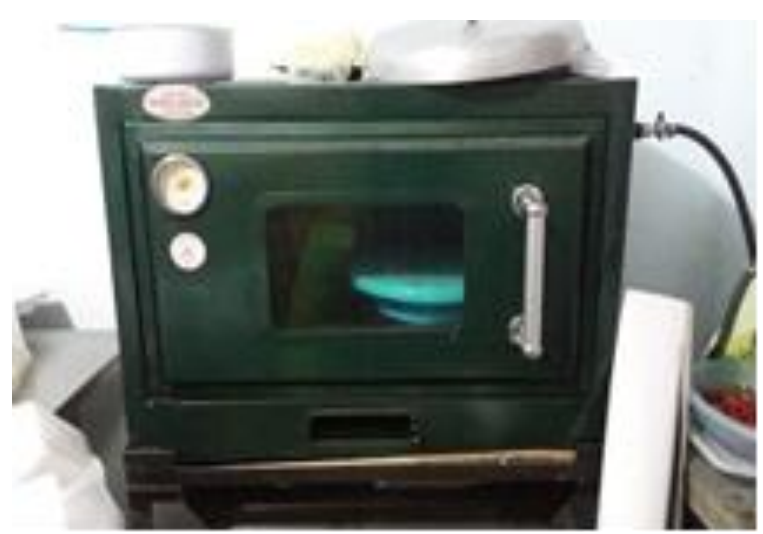

Gambar 2. Alat pengering Open

Pada proses pencampuran semua tepung dengan bumbu biang masih dilakukan dengan manual memakai ember. Pencampuran ini cukup membutuhkan waktu yang lama, karena untuk sekali mencampur hanya mampu dengan kapasitas $12,5 \mathrm{~kg}$ terigu. Jika dalam sekali proses digunakan $75 \mathrm{~kg}$ bahan baku berarti pencampuran dilakukan sebanyak 6 kali (6 batch). Akan sangat membantu jika ada mixer molen dengan kapasitas yang lebih besar dan cepat. 
Kemasan "Braling Gold" masih sangat sederhana. Dengan plastic transparan dan sablon satu warna. Pemberian barcode expired date (tanggal kadaluarsa) disablon sama dengan merek dagangnya.

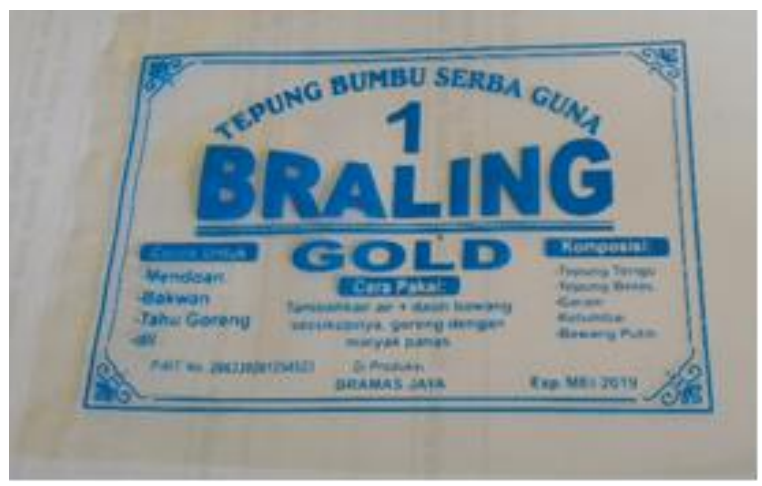

Gambar 3. Kemasan Braling Gold yang telah disablon

Proses pengemasan (packaging), yaitu tepung mendoan instan ditimbang sesuai takaran dan dikemas dengan wadah plastik kemudian disealer. Penimbangan dilakukan secara manual satu per satu. Demikan juga dengan proses pensealeran. Akan lebuh cepat jika menggunakan mesin packaging yang otomatis.

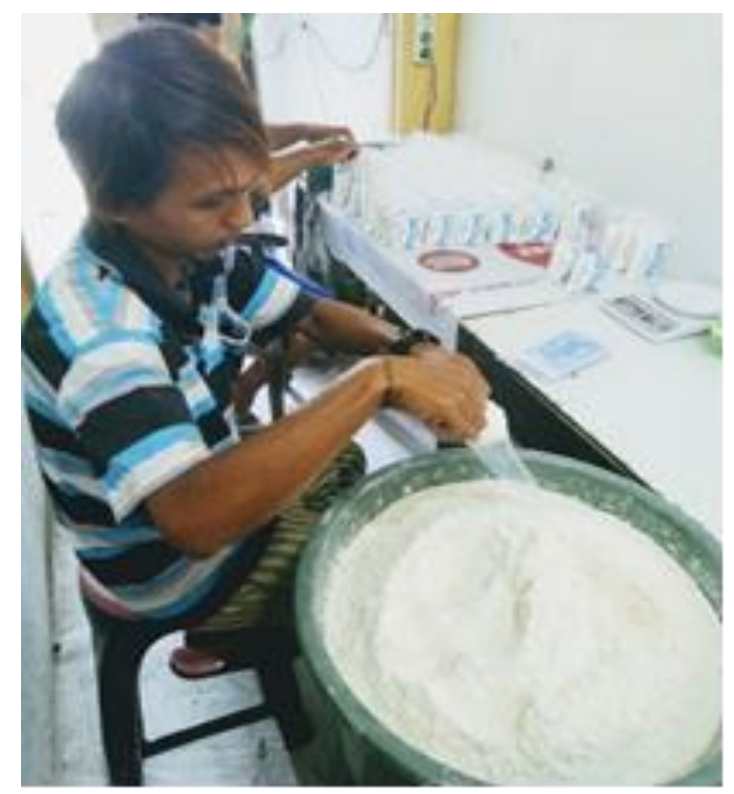

Gambar 4. Proses pengemasan

Proses akhir ini yang memakan waktu paling lama, sehingga berharap bisa mempunyai mesin packaging yang otomatis bisa menakar dan mensealer.

Jika diperhitungkan dalam sehari bekerja jam $08.00 \mathrm{~s} / \mathrm{d} 17.30$ (istirahat 1 jam) adalah 8,5 jam (510 menit) memproduksi 600 bungkus tepung mendoan instan dari 3 sak bahan baku $(75 \mathrm{~kg})$ tepung terigu. Dengan demikian membutuhkan waktu 0,85 menit/bungkus.

Dari semua permasalahan tersebut yang merupakan permaslahan utama atau bottleneck yang dihadapi oleh "Bramas Jaya" adalah saat melakukan pengemasan. Perlu 3 orang pekerja dalam proses pengemasan. Pekerjaan pengemasan terdiri dari pemasukan bahan ke plastik, penimbangan dan pen-sealeran. Jadi bottleneck utama industri ini adalah pada tahap pengemasan.

Dalam program pengabdian kepada masyarakat ini, untuk peningkatan kapasitas produksi tepung mendoan instan pada "Bramas Jaya" diberi bantuan alat packaging otomatis.

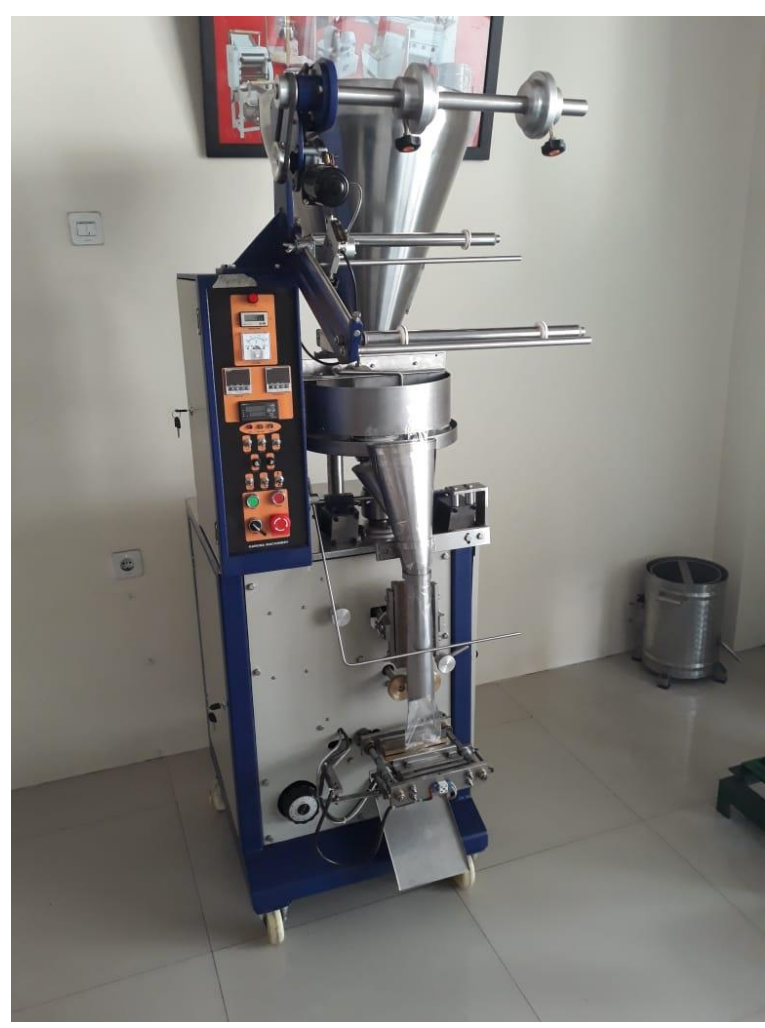

Gambar. 5. bantuan alat packaging otomatis 


\section{SIMPULAN DAN SARAN}

\begin{abstract}
Terbatasnya produksi tepung mendoan "Bramas Jaya" ini dikarenakan tidak adanya dukungan sarana dan prasarana yang memadai. Semua proses mulai dari pencampuran dan penyaringan tepung, pengolahan dan penyaringan bumbu, penimbangan serta pengemasan produk masih dilakukan secara manual. Saat ini kendala utama atau bottleneck yang dihadapi oleh "Bramas Jaya" adalah saat melakukan pengemasan. Perlu 3 orang pekerja dalam proses pengemasan. Pekerjaan pengemasan terdiri dari pemasukan bahan ke plastik, penimbangan dan pen-sealer-an. Jadi bottleneck utama industri ini adalah pada tahap pengemasan.
\end{abstract}

\section{DAFTAR RUJUKAN}

Anonim. 2012. Tempe: Persembahan Indonesia untuk Dunia. Badan Standarisasi Nasional, Jakarta.

Deden dan Budi, 2008, Kelayakan dan Skala Usaha Agrobisnis di Kecamatan Kembaran Kabupaten Banyumas, Dimensia Volume 5 nomer 1

\begin{tabular}{|c|c|}
\hline Disperindakop & (Dinas \\
\hline
\end{tabular}

Kabupaten Banyumas. 2008. Data Industri Kecil Kabupaten Banyumas. Purwokerto.

Ela Turmala Sutrisno Taufik Rahman Chandra Maulana, 2016, Optimalisasi Formula Tepung Bumbu Ayam Goreng Crispy Berbahan Baku Tepung Singkong (Manihot Esculenta Crantz) Modifikasi Autoclaving-Cooling Cycle, Program Studi Teknologi Pangan, Fakultas Teknik,Universitas Pasundan.

Marcia Aristya Dewana, 2017, Pengawasan Mutu Bahan Baku Kering Tepung Bumbu Serbaguna Original Di Pt Mitratama Rasa Sejati, Laporan kerja praktek, Program S

Studi Teknologi Pangan Fakultas Teknologi Pertanian Universitas Katolik Soegijapranata Semarang

Wahab, D. A. dan B. Dharmawan. 2008. Kelayakan dan skala usaha industri tempe di Kecamatan Kembaran Kabupaten Banyumas. Jurnal Dimensia 5 (1). 